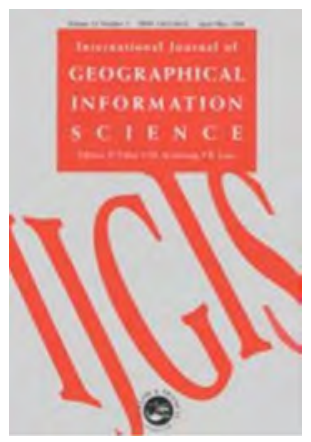

\title{
A new climatology of maximum and minimum temperature (1951-2010) in Spanish mainland: a comparison between three different interpolation methods
}

\begin{tabular}{|r|l|}
\hline Journal: & International Journal of Geographical Information Science \\
\hline Manuscript ID & IJGIS-2015-0479.R3 \\
\hline Manuscript Type: & Research Article \\
\hline Keywords: & $\begin{array}{l}\text { Climatology, Maximum Temperature, Minimum Temperature, Interpolation, } \\
\text { Spain }\end{array}$ \\
\hline \multicolumn{2}{|c}{} \\
\hline
\end{tabular}

SCHOLARONE

Manuscripts 
1 A new climatology of maximum and minimum temperature

\section{(1951-2010) in the Spanish mainland: a comparison between} three different interpolation methods

\begin{abstract}
This study presents a new climatology of monthly temperature for mainland Spain (1951-2010), performed with the highest quality and spatially dense, up-to-date monthly temperature data set available in the study area (MOTEDAS).
\end{abstract}

Three different interpolation techniques were evaluated: the Local Weighted Linear Regression (LWLR), the Regression-Kriging (RK) and the Regression-Kriging with stepwise selection (RKS), a modification of RK. The performances of the different models were evaluated by the leave-one-out validation procedure, comparing the results from the models with the original data and calculating different error measurements.

The three techniques performed better for Tmax than for Tmin, and for the cold, rather than warmer months; also at lower altitude than highland areas. The best results were achieved with LWLR applied for the first time on temperatures in the Spanish mainland. This method improved the accuracy of the temperature reconstruction with respect to RK and RKS.

We present a collection of Tmax and Tmin monthly charts, using the same temperature legend to prevent any visual bias in the interpretation of the results. The dataset is available upon request.

Key Words. Climatology; Interpolation; Maximum temperature; Minimum Temperature; Spain. 


\section{Introduction}

Climatology maps express mean values of climate variables and are used as a working tool in several fields, such as agriculture, engineering, hydrology, ecology and natural resource management among others (Daly et al., 2008). Moreover, climatology maps are a required element in searching for climate change signals, to evaluate climatic models and to understand how the climate interacts with other natural elements (Hofstra et al., 2008). According to the World Meteorological Organization, climatology maps should be developed using databases with recordings covering over 30 years. On the other hand, many research projects have pointed out that the reliability of climate analysis results increases when a high-quality, high spatial density dataset is used (Madden et al., 1993; Jones et al., 1999; Hofstra et al., 2008; Cowtan and Way, 2014).

Traditionally, climatology maps are produced from the spatial interpolation from the scant weather station series to obtain regularly distributed climatic information over a defined area. This is because of the necessity of organising the climatic information into continuous spatial fields of data to reduce the lack of information in some areas due to the irregular spatial distribution of the weather stations (Jones and Hulme, 1996; Dai et al., 1997; New et al., 2000). Until now, there has been no uniform consensus regarding what the most adequate interpolation method for climatic variables might be, and the best ones vary as a function of the area where they are applied and the interpolated variable (Vicente-Serrano et al., 2003). On the other hand, various methods for evaluating their performance have been proposed during the last few decades (Kurtzman and Kadmon, 1999; Goovaerts, 2000; Vicente-Serrano et al., 2003; Ninyerola et al., 2007; Hofstra et al., 2008; Li and Heap, 2011; Herrera et al., 2012).

Generally speaking, interpolation methods can be subdivided into four main groups: global, local, geostatistical and hybrid (Vicente-Serrano et al., 2003). Global methods (e.g. trend surface analysis and the regression models) use all the available spatial information to estimate the climatic values of the grid generated. These methods relate climate information with geographic data (elevation, latitude, slope, etc.) to generate the interpolated maps (Pons, 1996; Ninyerola et al., 2000). On the contrary, local methods (such as Inverse 
64 Distance Weighting, Nearest Neighbours, Delauny Thiessen and Minimum65 curvature-splines) only make use of the information obtained from subsets from 66 neighbouring stations; they usually assign weights to individual stations 67 according to a function that combines distance from the point to be estimated 68 and other characteristics or properties of neighbouring stations, such as the 69 Angular Distance Weighted method and Correlation Decay Distance index (New et al., 2000; Mitchell and Jones, 2005; Caesar et al., 2006; Hofstra et al., 2008).The geostatistical methods, like the Simple Kriging (Hengl et al., 2004), 72 Ordinary Kriging (Goovaerts, 2000), Co-Kriging (Nalder and Wein, 1998), 73 Universal Kriging (Hosseini et al., 1993) or Regression Kriging (Hengl, 2007; 74 Henglet al., 2007), assume that the spatial variability of a continuous variable 75 (or at least part of it) is too irregular to be modeled by a mathematical function,

\section{Study area} 2003). Lastly, hybrid methods combine elements from the above techniques to enhance the interpolation results (Ninyerola et al., 2007).

In this paper, we developed a new high resolution climatology for monthly mean values of maximum (Tmax) and minimum (Tmin) temperature in the western Mediterranean basin (mainland Spain) by using a recent high quality, high density dataset (acronym MOTEDAS, Monthly Temperature Dataset of Spain; Gonzalez-Hidalgo et al., 2015a). The new climatology emerges after comparing some of the best performing interpolation techniques, and the global results are shown in a complete collection of monthly maps of monthly mean maximum (Tmax), monthly mean minimum (Tmin) and monthly mean amplitude (Diurnal Temperature Range, DTR). The paper is organized as follows: in sections 2 and 3 we briefly describe the study area (Iberian Peninsula) and the dataset used in the new climatology; in section 4 we present the three interpolation methods and the error measurements used to estimate the performance of each one. Section 5 contains the accuracy of the models and their spatial differences by comparing various error measurements in several elevation bands, and concludes with the presentation of the new climatology and the collection of charts obtained from the best performing method. In section 6 , we discuss the main findings and present the main conclusion. 
The Spanish mainland (Iberian Peninsula, western Mediterranean basin) seems to be an appropriate area for evaluating the differences between interpolating approaches to temperature for several reasons. Firstly, its latitudinal position in the subtropical band suggests highly contrasting seasonal temperature regimes, while the north-south extension (c. $1000 \mathrm{~km}$ ) introduces a reasonable gradient in the amounts of incoming solar radiation; on the other hand, the Iberian Peninsula has sharply contrasting landscapes, well-defined by altitude combined with orography: the coastland areas (<200 m above sea level, asl), the inland plateau (200-1000 $\mathrm{m}$ asl), and the high mountain areas (>1000 m asl); finally the Iberian Peninsula is located between two heavily contrasting water masses (Atlantic Ocean and Mediterranean Sea). As a consequence, large areas in the inland plateau regions (meseta norte and meseta sur in Spanish), are only open to Atlantic influences from the west, due to the alignment of the mountain systems, which are arranged in a west-east direction, bound on the eastern side by a north-south oriented chain, the Sistema Iberico (see Figure 1). These reasons, among others, result in a marked complexity in spatial distribution of temperature across the Iberian Peninsula, as indicated in classic publications (Font Tullot, 1983; Capel Molina, 1998; Sánchez and Sánchez, 1999). As a consequence, the local multivariate regression models can be expected to be much more suitable than global methods to estimate the spatial gradients of temperatures in the Spanish mainland, and also to provide easier interpretation of factors that contribute to spatial distribution of temperatures. Such local methods have been applied with optimal results in territories characterized by complex orography (Daly et al., 2008; Frei, 2013; Brunetti et al., 2014) but not yet, to our knowledge, in the Spanish mainland.

\section{Data}

We have developed the new climatology of temperatures following the global approach of Mitchell and Jones (2005) and using the most recently updated database of monthly temperatures, the MOTEDAS dataset (GonzalezHidalgo et al. 2015a). MOTEDAS was developed after exhaustive analyses of the complete information stored at the National Meteorological Agency of Spain (AEMet). Quality control included detection of suspicious data and correction of 
132 inhomogeneities on a monthly scale (details in Gonzalez-Hidalgo et al. 2015a).

133 The MOTEDAS high resolution grid $(10 \times 10 \mathrm{~km})$ had previously been used to 134 analyse the spatial variability of monthly temperatures and their trends at high 135 resolution (Peña-Angulo et al., 2015, Gonzalez-Hidalgo et al., 2015b). In this 136 research, we used the complete information included in the MOTEDAS dataset, 137 in an attempt to maximize the information from the 3066 original series from 138 AEMet, which contains at least 84 months of original data. These series were 139 also checked by complementary quality control on their location (checks that 140 were not included in the original development of MOTEDAS). In short, the 141 locations of the 3066 stations were compared with a Digital Elevation Model 142 (DEM) obtained from the ASTER-based Global Digital Elevation Model (GDEM) 143 at a resolution of $30 \mathrm{~m}$ (Hayakawa et al., 2008). These one-by-one-degree files 144 can be downloaded from NASA's EOS data archive and/or Japan's Ground 145 Data System (http://gdem.ersdac.jspacesystems.or.jp/). The stations were 146 eventually discarded from the final data set for climatology reconstruction if the 147 following three criteria were satisfied: (1) difference in altitude $>150 \mathrm{~m}$ between 148 official coordinates and DEM, (2) the altitude of the station did not correspond 149 with any point of the DEM in the surrounding $2 \mathrm{~km}^{2}$, and (3) the difference in the 150 annual temperature mean value with respect to neighbouring stations was 151 higher than $3^{\circ} \mathrm{C}$, taking into account the lapse rate by altitudes. In the end, a 152 small percentage of the original series from MOTEDAS was discarded from the original 3066 stations (54 for Tmax and 45 for Tmin).

The final series (in terms of data availability) from MOTEDAS used in the development of temperature climatology were characterized as follows:

- Series with original complete information between 1951 and 2010 (11 stations).

- Series in which complete reconstruction was achieved between 1951-2010 with reference series from neighbouring stations no further away than 100 km (2865 stations in Tmax and 2869 in Tmin).

- Finally, in order to maximize the spatial information, the series in which MOTEDAS made an incomplete reconstruction but contained more than 7 years of original information between 1951-2010, were reconstructed following the approach suggested by (Brunetti et al. 2014). A total of 136 stations for Tmax and 141 of Tmin stations were saved using this procedure. 
166

167

168

169

170

171

172

173

174

175

176

177

178

179

180

181

182

183

184

185

186

187

188

189

190

191

192

193

194

195

196

197

198

199

The final dataset includes $40 \%$ of original and $60 \%$ of reconstructed data from stations no further than $25 \mathrm{~km}$ apart. Obviously individual station data varies, depending on the area and decade, with original data showing an increase in the 1981-2010 period.

Consequently, the version of MOTEDAS used to develop the new temperature climatology of the Spanish mainland includes a total number of 3012 for Tmax and 3021 for Tmin of complete, homogeneous and free from suspicious data monthly series (1951-2010; see Figure 2), and offers a significantly higher station density than those used in several previous climatologies for the Spanish mainland (1068 stations used by Ninyerola et al., 2005), and for the complete Iberian Peninsula (1440 stations used by Ninyerola et al., 2007; 237 stations used by Herrera et al., 2012). This procedure ensures that there is a reduced error bias in the series since a strong trend is displayed over the 1951-2010 period (see Gonzalez-Hidalgo et al., 2015a and b), and if station climate normals are calculated only from available data, the final result will be biased point by point, depending on the bias for the period covered by data from the stations surrounding each grid point.

\section{Interpolation methods}

Three different interpolation methods were compared: (1) Locally Weighted Linear Regression (LWLR), (2) Regression-Kriging (RK) and (3) Regression-Kriging with Stepwise selection (RKS). The resulting monthly Tmax and Tmin maps have a resolution of $0.0083^{\circ}(\sim 1 \mathrm{~km}$ at Iberian Peninsula latitude), which matches the spatial resolution of the GTOPO30 (USGS, 1996) Digital Elevation Model (DEM) on which the climatologies were reconstructed.

The DEM was used to assign geographic information to the stations, in addition to the elevation already available from station metadata together with latitude and longitude. For each cell of the DEM, we estimated the slope orientation, slope steepness and crossed distance from the sea (obtained by minimizing the sum of the cell-sea horizontal distance plus all vertical gradients crossed by the cell-sea segment) using the method described by (Brunetti et al., 2014) and we assigned the geographical parameters of the closest grid cell to each station. 
200

201

202

203

204

205

206

207

208

209

210

211

212

213

214

215

216

217

218

219

220

221

222

223

224

225

226

227

228

229

230

231

232

\subsection{Local Weighted Linear Regression (LWLR)}

The LWLR estimates locally the relationship between temperature and elevation (Brunetti et al., 2014), which represents an improvement on the geographically weighted regression (GWR) approach (Brunsdon et al., 1996) A weighted linear regression (Taylor, 1997), with neighbouring stations to predict the temperature $(T)$ value of a cell $(\lambda, \emptyset)$ as a function of the elevation, was estimated as follows:

$$
T(\lambda, \varnothing)=a(\lambda, \varnothing)+b(\lambda, \varnothing) * h(\lambda, \varnothing)
$$

where $a(\lambda, \varnothing)$ and $b(\lambda, \varnothing)$ are the linear regression coefficients, and $h(\lambda, \emptyset)$ the elevation.

The basic idea of the approach is to evaluate the relationship between temperature and elevation separately for each grid cell of the DEM, giving more importance to any nearby stations with topographical characteristics similar to those of the grid cell itself. Specifically, a number of neighbouring stations (at least 15 and no more than 35, - 35 being the number that minimizes the error) with the highest weights were used in the estimation of the regression for each grid point $(\lambda, \emptyset)$. The minimum and maximum number of neighbouring stations considered was determined by an analysis of interpolation accuracy by Root Mean Squared Error (RMSE). For each station, the weight was calculated as the product of the following weighting factors:

$$
w_{i}(\lambda, \emptyset)=w_{i}^{r}(\lambda, \emptyset) * w_{i}^{h}(\lambda, \emptyset) * w_{i}^{\text {dsea }}(\lambda, \emptyset) * w_{i}^{\text {slope }}(\lambda, \emptyset) * w_{i}^{\text {aspect }}(\lambda, \emptyset)(E q
$$

These weighting factors (position, height, distance from the sea, slope steepness and slope orientation) are based on Gaussian functions of the form:

$$
\mathrm{w}_{\mathrm{i}}^{\mathrm{var}}(\lambda, \emptyset)=\mathrm{e}^{-\left(\frac{\Delta_{\mathrm{i}}^{\mathrm{var}}(\lambda, \varnothing)^{2}}{c_{\mathrm{var}}}\right)}
$$

where $\Delta_{\mathrm{i}}^{\mathrm{var}}$ is the absolute value of the difference between the value of the specific variable in cell $(\lambda, \emptyset)$ and in the i-th station, and $c_{v a r}$ is a coefficient that 
233 expresses the decrease of the weighting function with increasing $\Delta_{\mathrm{i}}^{\mathrm{var}}$. The $\mathrm{c}_{\mathrm{var}}$

234 coefficients can also be expressed in terms of the value $\Delta_{\frac{1}{2}}^{\text {var }}$ which represent the

235 value of $\Delta_{\mathrm{i}}^{\mathrm{var}}$ for which the weighting factor is equal to 0.5 .

236

237

$\mathrm{c}_{\mathrm{var}}=-\frac{\left(\Delta_{\frac{1}{2}}^{\mathrm{var}}\right)^{2}}{\ln 2}$

238

239

To select the most appropriate $\Delta_{\frac{1}{2}}^{\mathrm{var}}$ values to be used in the weighting

240

factors, we followed an iterative process, and the $\Delta_{\frac{1}{2}}^{\mathrm{var}}$ producing the lowest

241

possible error at station locations was estimated for each month.

242

The most relevant weight is the radial, which is the optimization of the $\Delta_{\frac{1}{2}}^{\mathrm{r}}$

243 factor producing the largest improvement in interpolation performance. Its

244 optimal values vary from month to month, with lower values in summer $(24 \mathrm{~km}$

245 in July) and higher in winter (58 km in February) for Tmax; on the contrary, for

246 Tmin, lower values were found in winter (18 km from November to February),

247 and higher values in spring and summer (24 km from April to July).

248 The other halving factors $\left(\Delta_{1 / 2}^{\mathrm{h}}, \Delta_{1 / 2}^{\mathrm{dsea}}, \Delta_{1 / 2}^{\text {slope }}, \Delta_{1 / 2}^{\text {aspect }}\right)$ were set as in

249 Brunetti et al.(2014).

250

251

4.2. Regression-Kriging (RK)

252

The RK method combines a regression model with a Kriging (Hengl et al.

253

2007) of the regression residuals (Tveito et al., 2008; Di Piazza et al., 2011;

254

Brunetti et al., 2014).

255

In this case, we first estimated the temperature vs. elevation $(h)$ linear

256 regression model as in Eq. 1, but with a global approach, i.e. with $a$ and $b$

257 coefficients identical for each grid cell and dependent only on the month in

258 question. A Kriging interpolation was then applied to the residuals from this

259 model. This technique can be used to obtain a variogram providing information

260 on the spatial correlation of the analysed residuals. In this study, we took into

261 account all pairs of stations in the range of $250 \mathrm{~km}$, and grouped them

262 according to distance intervals of $10 \mathrm{Km}$. The exponential variogram was 
263 selected to model the dependency between the semivariance and the distance, 264 as this provided the lowest error.

265 The theoretical variogram was used to obtain the covariance $(C)$ vs 266 distance, and the covariance matrix, expressing the covariance of any pair of

267 stations. The array with the Kriging weights $(\boldsymbol{k})$ for each cell $(\lambda, \emptyset)$ was obtained 268 as follows:

where $c_{0}$ is the array representing the covariance of the cell $(\lambda, \varnothing)$ with all the station positions. The temperature of each cell was thus estimated as follows:

274

275

276

$$
\boldsymbol{k}(\lambda, \emptyset)=\boldsymbol{C}^{-1 *} \boldsymbol{c}_{\mathbf{0}}(\lambda, \emptyset)
$$

$$
\text { station positions. The temperature of each cell was thus estimated as follows: }
$$$$
T=a+b^{*} h(\lambda, \emptyset)+\boldsymbol{k}^{T}(\lambda, \emptyset) * \boldsymbol{\epsilon}
$$

where $a$ and $b$ are parameters defined by the global regression model, $\mathrm{h}$ is the elevation, $\boldsymbol{k}^{\boldsymbol{T}}$ is the vector of the Kriging weights, and $\boldsymbol{\epsilon}$ the vector of station residuals.

280

\subsection{Regression Kriging with Stepwise selection (RKS)}

The third interpolation method used in this study was a variation of the previously described RK. In this case the Kriging is used to interpolate the residuals from a multi-linear regression model (slope steepness, slope orientation, distance from the sea, altitude, longitude, and latitude) with stepwise selection. The stepwise selection method allows us to choose the optimum independent variables that will be used in the multi-linear regression model for each month. This method integrates the variables in an iterative way: in each step it evaluates which set of variables should be included in the model. The algorithm stops when the model does not make any further improvements, either by introducing or removing variables. The relative quality of the model is evaluated with Akaike's information criterion (AIC). The AIC is a measure of the relative quality of a fitting model. The lower the AIC value, the better the model.

As in the previous method, a Kriging interpolation was applied to the residuals from the multi-linear regression. To this end, all pairs of stations in the range of $250 \mathrm{~km}$ were taken and grouped according to distance intervals of 10 
$297 \mathrm{~km}$. Finally, we selected the exponential variogram to model the dependency

298 between the semivariance and the distance.

299 In this way, the temperature in each cell was estimated by the following 300 equation:

301

302

303

304

305

306

where coefficients $\mathrm{a}, \mathrm{b} \ldots, \mathrm{g}$ not excluded by the stepwise selection iterative procedure were determined with the regression model.

307

308

309

310

311

312

\subsection{Validation procedure and error measurements}

The performances of the three interpolation models were evaluated by using a leave-one-out validation procedure; the monthly value from each station was excluded from the dataset and reconstructed by the three models, using all the other stations; finally, the estimated value was compared with the observed value. This procedure ensured a higher level of accuracy with respect to the classic approach of leaving a fixed percentage of original data for the validation procedure, because in the leave-one-out, all the original data involved in the model are checked individually with their specific model.

Four error measures were computed to compare the performances of the interpolation methods: the Mean Bias Error (MBE), the Mean Absolute Error (MAE), the Root Mean Squared Error (RMSE), and the Index of Agreement (D) developed by (Willmott 1982). The MBE provides information on the tendency of the model to systematically overestimate or underestimate a variable (Pielke, 1984). The Mean Absolute Error (MAE) is the average of the differences (in

323 terms of absolute value) between that observed and that predicted by the model. The Root Mean Squared Error (RMSE) estimates the average difference between estimated and observed values in each station. The RMSE and MAE summarize the average difference between the estimated and real values with the same units (Vicente-Serrano et al., 2003); Willmott (1982) suggested that RMSE was more appropriate than MAE in order to validate spatial interpolation models, although Vicente-Serrano et al. (2003) indicated that MAE is less sensitive than RMSE when dealing with extreme values. In this respect, RMSE 
331 is stricter than MAE. The Index of Agreement (D) is a standardized measure of

332 the model prediction error and varies between 0 and 1. A value of 1 indicates a

333 perfect match, and 0 indicates no agreement at all (Willmott, 1982). Index D can

334 detect proportional differences in the observed and estimated means and

335 variances; however, it is too sensitive to extreme values, due to the squared

336 differences (Legates and McCabe, 1999).

337 Finally, the global quality of the model was also evaluated by the 338 coefficient of determination $\left(R^{2}\right)$ as a square of the multiple Pearson correlation 339 coefficient. This coefficient not only gives information on the quality of a model, 340 but also on its capacity for prediction under the assumption of explained 341 variance.

342

343

344

5. Results

\subsection{Global accuracy of models}

The global results of interpolation methods evaluated by various error measurements (MBE, MAE, RMSE, $\mathrm{R}^{2}$ and $\mathrm{D}$ ) are shown in Tables 1 and 2 for Tmax and Tmin on an annual and monthly scale. The performances are better for Tmax than for Tmin, both on a monthly and annual scale, with MAE and RMSE being lower for Tmax than for Tmin, and the reverse being true for $D$ and $350 \quad \mathrm{R}^{2}$ (Tables 1 and 2).

351 Errors are always maximum in summer, for both Tmax and Tmin, and the 352 lowest errors are in winter for Tmax and in spring for Tmin. In particular, the 353 highest values of RSME range from 1.16 to $1.27^{\circ} \mathrm{C}$ in July for Tmax, and from 3541.26 to $1.32^{\circ} \mathrm{C}$ in August for Tmin, while its lowest values range from 0.81 to $3550.83^{\circ} \mathrm{C}$ in February for Tmax and from 0.97 to $1.05^{\circ} \mathrm{C}$ in April for Tmin. The 356 lowest RMSE values of these ranges are those from the LWLR method. The 357 same annual cycle in RMSE, but with higher values, was presented in the 358 previous climatology of the Spanish mainland by (Ninyerola et al., 2005), in 359 which the lowest RMSE values were $1.6^{\circ} \mathrm{C}$ in July for Tmax and $1.5^{\circ} \mathrm{C}$ in August 360 for Tmin, and its highest values were $1.1^{\circ} \mathrm{C}$ in February for Tmax and 1.1 in 361 April for Tmin. These results can also be deduced from the MAE, $R^{2}$ and $D$. 362 These findings coincide with the spatial variability of temperatures evaluated by 363 the Correlation Distance Decay by (Peña-Angulo et al., 2015), with the lowest 
364 RMSE values relating to the months characterized by highest spatial 365 coherence.

366 In the Spanish mainland, the best performing model is always the LWLR, 367 and the worst is the RK. Differences among models are much more evident for 368 Tmin than for Tmax. Looking at RMSE, there is a maximum range between best 369 and worst performing method of about $0.1^{\circ} \mathrm{C}$ in summer for Tmax and about $370 \quad 0.2^{\circ} \mathrm{C}$ in autumn for $\operatorname{Tmin}$. The $\operatorname{MAE}\left({ }^{\circ} \mathrm{C}\right)$ also shows that the lowest error is 371 returned by the LWLR method, where values between 0.61 and 0.88 are 372 achieved according to the month; in second place is the RKS, with values 373 between 0.60 and 0.89 ; and finally the RK between 0.61 and 0.94 .

\subsection{Performance of the models vs elevation}

These global results must be taken with caution, since they refer to a very complex terrain in which the effects of distance from water bodies, altitude, and latitude are combined. In particular, we verified whether the accuracy of the models for Tmax and Tmin changes with altitude. Figure 3 shows the mean annual values of MBE for different elevation bands, together with January and July. This estimator allows us to identify systematic over/under estimations. In general, the three models produce lower MBE at low altitude, but MBE values increase in the highlands, particularly above $1000 \mathrm{~m}$ asl, where there is a systematic overestimation of Tmax, and a systematic underestimation of Tmin. This phenomenon is important for RK and RKS, where bias can reach several tenths of a degree for the highest elevation bands (with Tmax/Tmin biases of $+0.58 /-0.93^{\circ} \mathrm{C}$ and $+0.49 /-0.63^{\circ} \mathrm{C}$ above $1200 \mathrm{~m}$ for RK and RKS respectively), but much lower for the LWLR method (Figure 3). The same pattern was observed in the other error measurements (figure not shown).

The analyses of monthly model performance versus altitude show 391 differences between cold and warm months and the systematic errors in the 392 various elevation bands are much more evident. In Figure 3, the January and 393 July (as representative of cold and warm periods) monthly values of MBE for 394 LWLR, RK and RKS at different altitude intervals are shown, which roughly 395 correspond to coastland areas (<200 $\mathrm{m}$ asl), inland plateaus and inland catchments (200-1000 m asl), and mountain landscapes (>1000 m asl). 
The negative systematic biases at high elevation bands for Tmin range

398

399

400

401

402

403

404

405

406

407

408

409

410

411

412

413

414

415

416

417

418

419

420

421

422

423

424

425

426

427

428

429 between $-0.61^{\circ} \mathrm{C}$ and $-1.20^{\circ} \mathrm{C}$ in the $\mathrm{RK}$ model, in summer and winter respectively. On the contrary, LWLR presents lower biases in winter than in summer, with values ranging from $-0.11^{\circ} \mathrm{C}$ in winter to $-0.19^{\circ} \mathrm{C}$ in summer. RKS has minimum biases in spring $\left(-0.43^{\circ} \mathrm{C}\right)$ and maximum in autumn $\left(-0.83^{\circ} \mathrm{C}\right)$. As for Tmax , monthly biases above $1200 \mathrm{~m}$ asl are negative in winter and positive from March to November (not shown in the figure) for RK (ranging from $-0.33^{\circ} \mathrm{C}$ in December to $+1.28^{\circ} \mathrm{C}$ in July), and always positive for RKS (ranging from $+0.08^{\circ} \mathrm{C}$ in December to +0.73 in July). No relevant biases are observed for Tmax in the LWLR model.

In low elevation bands, systematic errors are smaller or absent, depending on the model and the season. LWLR presents no systematic errors below $1000 \mathrm{~m}$ in any month, either for Tmax or Tmin, and biases are always lower than $0.1^{\circ} \mathrm{C}$ (negative or positive). RK, on the contrary, has positive (negative) systematic biases, up to $+0.2^{\circ} \mathrm{C}\left(-0.2^{\circ} \mathrm{C}\right)$ in winter (summer) months for Tmin (Tmax). The same is true for RKS, with errors up to $+0.17^{\circ} \mathrm{C}$ in autumn Tmin and up to -0.15 in summer Tmin.

\subsection{Climatology maps of maximum and minimum temperature, and DTR.}

The classic analyses of spatial distribution of Tmax and Tmin in the Spanish mainland (Font Tullot, 1983, Capel Molina, 1998), and the most recent climatologies (Ninyerola et al., 2007, AEMet, 2011), have shown that the spatial distribution of the isotherms in the Iberian Peninsula varies according to the latitude, distance from the sea and elevation, with large spatial variations throughout the year, i.e.: temperatures increase from north to south, in coastal areas the gradients are smoothed, and the orography is the principal factor driving the spatial distribution of Tmax and Tmin values. Furthermore, due to the west-east orientation of the mountain systems and the fact that the inland plateaus are open to the west (see Figure 1), the influence of the Atlantic Ocean on temperatures spreads over a large area of inland Spain to the east, while the influence of the Mediterranean is limited to a small area, due to the vicinity of the mountain systems in the southern and eastern coastal areas; this leads to a second main gradient from west to east being identified in the classic maps. 
The above results suggest that the global method (such as RK and RKS)

431

432

433

434

435

436

437

438

439

440

441

442

443

444

445

446

447

448

449

450

451

452

453

454

455

456

457

458

459

460

461

462

463 are not the most suitable for capturing the complex interrelation of these factors affecting the temperature spatial gradients in the Spanish mainland and causing the near-surface temperature to change significantly from region to region. Our results indicate that the most adequate approach is a local estimate of the temperature lapse rate, made by using the information from the most representative stations in that location, as the LWLR method does. In the following paragraphs, we will take the climatologies produced with the LWLR approach as the base of reference for the Spanish mainland, and describe their main features.

\subsubsection{The Tmax climatology}

Tmax climatology maps are shown in figure 4 (see also Figure 1 for spatial identification).

During winter (December to February), most of the Spanish mainland has Tmax values below $15^{\circ} \mathrm{C}$, except for small areas in the extreme coastland to the south-west and east. The inland Tmax spatial distribution is characterized by the contrast between inland catchments and their mountain borders with the Mediterranean and south-west coastland areas, with the isotherm of $15^{\circ} \mathrm{C}$ as a limit. The Tmax mean value in the northern plateau (Duero basin) is lower $\left(<10^{\circ} \mathrm{C}\right)$ than in the southern inland catchments of Tagus, Guadiana and Guadalquivir, and the Ebro inland in the north-east $\left(>10^{\circ} \mathrm{C}\right)$. Finally, in the southern plateau (but not in the northern inland Duero catchment) a clear westeast gradient is identified, accentuated during the month of February. Month by month, the areas below $10^{\circ} \mathrm{C}$ are restricted to the mountain regions and eastern part of the northern Duero basin.

Between March and May, the north-south gradient remains between inland catchments; in southern ones, Tmax values above $20^{\circ} \mathrm{C}$ are found in March in the southernmost areas (Guadalquivir basin) and extend to the rest of the southern catchment and Ebro basin to the north-east during April and May; the Duero catchment, in the northern plateau, reaches an isothermal value of $20^{\circ} \mathrm{C}$ only in May in its western area, one month later than the other inland areas. The Tmax value in the north-eastern Ebro basin is quite similar to the southern catchment, i.e. the latitude (quite similar to the Duero basin) does not 
464 seem to be a determining factor for Tmax during these months. In April and 465 May, Tmax values below $15^{\circ} \mathrm{C}$ are found only in mountain areas and the 466 eastern Duero catchment in the northern inland plateau. The coastland areas 467 behave in a different way, depending on their position (Atlantic versus 468 Mediterranean water bodies). In the Mediterranean coastland to the east and in 469 the south, Tmax is above $20^{\circ} \mathrm{C}$, while in the northern coastland it is $>15^{\circ} \mathrm{C}$. 470 Month by month, Tmax values above $25^{\circ} \mathrm{C}$ increase along the axis of the main 471 rivers (Tagus, Guadiana, Guadalquivir and Segura catchment). In May, the 472 value of Tmax in the Spanish mainland is above $20^{\circ} \mathrm{C}$, except in mountain 473 areas and the northern coast.

474 The warm season lasts from June to September, and a clear north-south 475 gradient is detected in Tmax, with mountain areas isolated from the surrounding 476 landscapes by the isothermal value of $20^{\circ} \mathrm{C}$. The maximum values of Tmax are 477 found in the southern plateau and central area of the Ebro basin to the north478 east $\left(>30^{\circ} \mathrm{C}\right)$. The coastal areas differ again between Atlantic and 479 Mediterranean, with the Mediterranean coastland presenting Tmax values 480 similar to inland southern catchments.

481 June and September show a similar spatial distribution of Tmax values. 482 In both cases, the north-south separation is defined by the $25^{\circ} \mathrm{C}$ isotherm and, 483 in extended areas of the southern Spanish mainland, Tmax is above $25^{\circ} \mathrm{C}$. On 484 the other hand, the spatial distribution of Tmax in July and August is quite 485 similar, showing the same north-south gradient, with the threshold between 486 north and south being the $30^{\circ} \mathrm{C}$ isotherm. In the southern inland areas, Tmax 487 values are $>35^{\circ} \mathrm{C}$.

488 October and November seem to be transitional months. During October 489 the Tmax spatial distribution resembles that of the warmest months (north-south 490 gradient, differences between coastal areas, isolated mountain areas) with 491 lower mean values. The coastland-inland and north-south gradients are clearly 492 separated by the $20^{\circ} \mathrm{C}$ isotherm in October, and $15^{\circ} \mathrm{C}$ in November. In the 493 highland inland areas, Tmax values are below $15^{\circ} \mathrm{C}$. Globally, the spatial 494 distribution of Tmax in October is similar to May, and November to March. 495 Finally, in November the inland northern Duero basin Tmax is similar to the 496 surrounding mountain areas where, in the highest places, it falls below $5^{\circ} \mathrm{C}$. 
497 Only in the Mediterranean coastal and south-western areas are Tmax values 498 above $15^{\circ} \mathrm{C}$.

499 In brief, Tmax spatial monthly distribution shows a north-south gradient in 500 the inland catchments, accentuated during the warmest months by a higher 501 increase in southern Tmax values. Mountain areas in the warmest months are 502 cold and isolated from the surrounding areas, i.e. altitude affects spatial 503 variability of Tmax, particularly when solar radiation is at maximum. In addition 504 to a north to south gradient, there is also a west-east gradient. This combination 505 of latitudinal gradient and relative position (oriented to sea influences from the 506 west or east) seems to explain the differences between catchments located at 507 the same latitude, such as the Duero and Ebro: a combination of the sheltering 508 effect of mountain systems, prevalent westerly wind circulation and different 509 effects from the Atlantic and Mediterranean water bodies emerge as a plausible 510 explanation of Tmax differences between the Duero and Ebro basins located at 511 the same latitude.

\section{$512 \quad$ 5.3.2. Tmin climatology}

513 Tmin climatology maps are shown in figure 5 (see also Figure 1 for 514 spatial identification).

515 In general, the spatial differences of Tmin values are lower than for Tmax 516 and this is particularly true during the warmest months producing a monthly 517 amplitude (Tmax-Tmin) spatially variable throughout the year (see below).

518 From November to April, the spatial distribution of Tmin is similar and 519 most of the Spanish conterminous land is below $5^{\circ} \mathrm{C}$, except in small areas in 520 the eastern and southern coastland. The lowest values can be found in 521 December, January and February in mountain areas and the Duero basin in the 522 northern plateau (Tmin below $0^{\circ} \mathrm{C}$ ), with a clear north to south gradient, while 523 the southern inland catchments and Ebro basin to the north-east are above $0^{\circ} \mathrm{C}$.

524 In the southern catchments of the Tagus, Guadiana and Guadalquivir, a west525 east gradient in Tmin is detected. The differences between coastal and inland 526 areas are lower than for Tmax. In November, March and April the area between $5275^{\circ} \mathrm{C}$ and $10^{\circ} \mathrm{C}$ in Tmin extends to the south-west. The $<0^{\circ} \mathrm{C}$ value of $\mathrm{Tmin}$ is 528 restricted to mountain areas in March and April. 
529 In May, the spatial distribution of Tmin along the north-south gradient 530 between catchments $\left(10^{\circ} \mathrm{C}\right.$ as a limit between north and south) is more

531 complex; the Ebro basin exhibits similar values to southern basins $\left(>10^{\circ} \mathrm{C}\right)$ and 532 in the southern part of the Spanish mainland there is a west to east gradient. 533 During May, the $10^{\circ} \mathrm{C}$ isotherm moves inland from the $\mathrm{SW}$ of the southern 534 catchments and Mediterranean coastal areas, while northern coastland Tmin 535 values are $<10^{\circ} \mathrm{C}$.

536 The warmest period from June to September shows a clear north-south 537 gradient with the $15^{\circ} \mathrm{C}$ isotherm separating the north from the south in July538 August, and $10^{\circ} \mathrm{C}$ in June and September. Tmin values of $<5^{\circ} \mathrm{C}$ are restricted to 539 mountain areas and the $15^{\circ} \mathrm{C}$ isotherm also seems to be the boundary between 540 inland and coastal to the east and south. Except for July and August, Tmin 541 values in the Ebro basin are similar to the Duero basin at the same latitude.

542 In brief, the spatial differences of Tmin values seem lower than Tmax. In 543 addition, north-to-south, west-to-east or east-to-west gradients according to 544 latitudinal position and proximity of different water bodies, are simplified.

545

546

547

548

549

550

551

\subsubsection{The DTR climatology}

Lastly, Figure 6 shows the DTR monthly collection charts. Generally speaking, during the warmest months (June to September) there is a clear inland-coastland gradient in the DTR values, which are higher inland. Along the Mediterranean fringe and northern coastland the DTR values vary between $6^{\circ} \mathrm{C}$ $8^{\circ} \mathrm{C}$, while inland they vary between $10^{\circ} \mathrm{C}-12^{\circ} \mathrm{C}$, (see Figure 6 ), with maximum 552 values over $18^{\circ} \mathrm{C}$.

The coastland-inland pattern during October-February disappears, when

554 the lowest DTR values of $6^{\circ} \mathrm{C}$ to $8^{\circ} \mathrm{C}$ are found in the northern coastal areas, 555 and increase toward the central inland and southern areas, where the monthly 556 DTR is $10^{\circ} \mathrm{C}$ to $12^{\circ} \mathrm{C}$. From March to May, the Atlantic coastland to the north 557 and west differs from the Mediterranean southern coastland, with DTR values 558 lower in the Atlantic coastal area $\left(6^{\circ} \mathrm{C}-8^{\circ} \mathrm{C}\right)$ than the Mediterranean eastern 559 coast $\left(10^{\circ} \mathrm{C}-12^{\circ} \mathrm{C}\right)$. The inland areas show DTR between $6^{\circ} \mathrm{C}$ and $12^{\circ} \mathrm{C}$. In 560 May, the DTR values inland are over $14^{\circ} \mathrm{C}$.

561 In brief, the DTR monthly spatial distribution indicates that the maximum 562 values are reached inland during the summer months when there is a clear 
563 difference between coastal and inland areas. During the coldest months this 564 pattern disappears, and a north-south gradient predominates in the DTR 565 monthly values, increasing toward the south. The maximum spatial differences 566 in DTR values have been found in July and August (coastland $6^{\circ} \mathrm{C}-8^{\circ} \mathrm{C}$, inland $567>18^{\circ} \mathrm{C}$ ); meanwhile during the coldest months, the maximum spatial differences 568 vary between $4^{\circ} \mathrm{C}-6^{\circ} \mathrm{C}$ in coastal areas and $8^{\circ} \mathrm{C}-10^{\circ} \mathrm{C}$ inland. A plausible 569 explanation is that Tmax in the coldest months is strongly affected by factors 570 such as air humidity or cloud to a higher degree than those factors that can 571 promote spatial variability in Tmin.

572

\section{6. Discussion and conclusions}

\section{6.1. Global comments}

575 We applied different interpolation approaches to the recent high quality and up-to-date monthly temperatures dataset of Spain (MOTEDAS), with the aim of producing a new high resolution climatology for Tmax and Tmin in the Spanish mainland. The poorest results were observed in summer for both Tmax and Tmin data, while better results were found in winter for Tmax and in spring for Tmin. The comparison between models indicates that the estimation errors vary as a function of the altitude and a generalized underestimation/overestimation of Tmin/Tmax was detected particularly at $>1000 \mathrm{~m}$ where the LWLR method performed best.

The quality of dataset used and the high spatial density of stations in this research is probably the most relevant reason for the general improvement of the RMSE with respect to previous climatologies (Ninyerola et al., 2005), or when comparing the $\mathrm{R}^{2}$ coefficients of annual mean values obtained from 1350 stations (Ninyerola et al. 2007), with those obtained in this research (see Tables 1 and 2). Therefore, all the three methods applied are an improvement on 590 previous results.

591 The global difference between the performance of the models for Tmax 592 and Tmin can be attributed to the various factors affecting these, because Tmax 593 depends more on global factors, such as radiation defined by latitudinal 594 position, while Tmin could be more heavily affected by local factors, such as 595 land use associated with the albedo, latent heat fluxes etc. (Christy et al., 2009; 596 Klotzbach et al., 2009; McNider et al., 2010), which are more difficult to 
597 implement in the models and not always captured by the available station data.

598 Within this context it would be interesting to verify whether the three methods

599 produce systematic errors at a local level, when selected station clusters are 600 included.

601 All three models produced the worst results in highland areas, particularly 602 for Tmin in summer. Again, the LWLR returned the best results, in particular 603 above $1000 \mathrm{~m}$ asl for both Tmax and Tmin (Figure 3). The worst model is RK 604 and it is interesting to note the improvements provided by the introduction of the 605 stepwise selection method in the RKS model, which means that the introduction 606 of additional variables to estimate temperature fields in the different months 607 gives better results, in Tmax during summer and in Tmin, in particular, during 608 winter. The relevance of the variables differs from month to month, also 609 between Tmax and Tmin. The slope orientation was considered only for Tmax 610 in the cold months (January, December, and in October) and September. In 611 February, the distance from the sea was not included in the model, while in 612 November the longitude was excluded. With Tmin, all the geographic variables 613 were relevant in the model except for the longitude in April.

614 The analyses of the coefficients of the multilinear regression allowed us 615 to compare the role of the different independent variables (predictors) on Tmax 616 and Tmin. The elevation effect (representing the global lapse rate) is stronger in 617 spring and autumn for Tmax and in summer for Tmin. The latitude coefficients 618 show a higher effect on temperature in summer (both for Tmax and Tmin) and 619 more for Tmax than Tmin, according to a strict relationship with incoming solar 620 radiation. The effect of slope steepness is positive in Tmin in all months, and 621 negative in Tmax between March-October. In Tmax, the maximum effect of 622 slope was found during summer, while in Tmin the strongest effect was found in 623 cold months. Slope orientation is positive in all months and more important in 624 winter in Tmin, while it seems to be less relevant for Tmax; also distance from 625 the sea is more significant during summer than winter.

626 The overall spatial variability of temperatures and the relevance of 627 different geographical variables, in addition to the elevation, in driving this 628 variability has been well identified by several models for the Spanish mainland. 629 Ninyerola et al. $(2005,2007)$ applied a combination of a multiple regression with 630 residuals correction by means of local and geostatistical techniques, while the 
631 Spanish Meteorological Agency (AEMet, 2011) applied a multivariate regression 632 interpolation method with a residuals correction, performed with either a local 633 (Inverse Distance Weighted) or a geostatistical method (Simple Kriging).

634 However, as well as the different role of these variables throughout the 635 year, there is an important spatial variability in their effect on temperature. This 636 is demonstrated by the fact that the local approach of the LWLR model (which 637 includes all the variables in the station weighting procedure) allows for the 638 spatial variability of the temperature lapse rate (linked to the geographical 639 aspects) to be better captured in the different months of the year, providing 640 lower errors at each elevation band, even without any further interpolation of the 641 residuals.

642

\subsection{Final remarks}

The new approach proposed in the present paper by using LWLR seems to be an improvement on the previous ones, at the present level of development of interpolation techniques, due to the decrease in the global error values (at high altitude in particular) and, even more important, because of the elimination of systematic biases at different elevation bands.

In conclusion, the analyses of error measurements and their spatial and 650 temporal distribution indicated that the approach proposed in this paper, the 651 LWLR method, as compared to the generalized RK and the RKS, improves the 652 previous climatologies in the Spanish mainland, and should be suggested for 653 future research.

Nevertheless, even though in our case LWLR turned out to be the most appropriate approach, this result cannot be generalized. In particular, the LWLR method is more dependent on the availability of station data than RK and RKS and any global approach in general. For other datasets, RK and RKS may be more suitable, either because they are simpler to use or because station density 659 is not sufficient to apply LWLR.

As well as better performance in terms of station errors, LWLR has the additional advantage of estimating a prediction interval for any grid point in the terrain studied. Since LWLR uses weighted linear regression to estimate temperature as a function of elevation, standard methods for calculating 664 prediction intervals for the dependent variable can be used as in Daly et 
665 al.(2008). The procedure consists in estimating the variance of the temperature 666 (T) of a grid-point at elevation $h$ as:

667

668

$$
s^{2}\left\{T_{h}\right\}=s^{2}\left\{\hat{T}_{h}\right\}+M S E
$$

669

where MSE is the mean square error of the observed station temperatures compared to those obtained with the regression model.

This estimation takes into account both the variation in the possible location of the expected temperature for a given elevation $\left(s^{2}\left\{\hat{T}_{h}\right\}\right)$ linked to the 674 regression coefficient errors and the variation of the individual station 675 temperatures around the regression line (MSE).

$$
s^{2}\left\{T_{h}\right\}=M S E \cdot\left\{1+\frac{1}{\Sigma w_{i}}+\frac{(h-\bar{h})^{2}}{\Sigma\left(w_{i} h_{i}-\bar{h}\right)^{2}}\right\}
$$

680

681

where $i$ ranges over the stations involved in the grid point reconstruction.

The prediction interval at significance level $\alpha$ can be estimated as:

$$
T_{h} \pm t_{\frac{1-\alpha}{2}, d f} \cdot s\left\{T_{h}\right\}
$$

where $t$ is the value of a Student distribution with $d f$ degrees of freedom corresponding to cumulative probability $(1-\alpha) / 2$.

In Figure 7, the $68 \%$ confidence interval (we chose $68 \%$ in order to find prediction intervals easily comparable with the station leave-one-out RMSE) for January and July is presented as an example. The confidence interval is higher in summer than in winter and for Tmin than for Tmax, i.e. when the spatial coherence is lower. These maps allow us to understand where station density should be enhanced to improve confidence in the reconstruction.

The most critical areas are mountains in summer for Tmax, while Tmin seems to be more sensitive to station density, showing higher confidence intervals where station density is lower. 
696 These are the areas where the new climatology should be taken with 697 more caution, not only because of the scarcity of stations to validate any model, 698 but also as a consequence of the larger confidence interval of the model 699 algorithms in these areas.

700 We offer a collection of monthly charts for the Spanish mainland for the 701 period between 1951 and 2010. The climatology is available upon request.

702

703

704

705

706

707

708

709

710

711

712

713

714

715

716

717

718

719

720

721

722

723

724

725

726

727

728

729

\section{Acknowledgments}

This study was supported by the Ministry of Science and Innovation, (Spanish Government), projects: the Hydrological Impacts of Global Warming in Spain (HIDROCAES, CGL2011-27574-C02-01) and the Development of Drought Index in Spain (DESEMON, CGL2014-52135-C3-3-R); Gobierno Regional de Aragón DGA-FSE (Grupo de Investigación Consolidado "Clima, Agua, Cambio Global y Sistemas Naturales"). Original data from AEMet (Spanish National Meteorological Agency).

\section{References}

AEMet, 2011. Atlas climático ibérico/ Iberian climate atlas. Agencia Estatal de Meteorología, Ministerio de Medio Ambiente y Medio Rural y Marino.Madrid.

Brunetti, M., Maugeri, M., Nanni, T., Simolo, C. and Spinoni, J., 2014. Highresolution temperature climatology for Italy: interpolation method intercomparison. International Journal of Climatology, 34 (4), 1278-1296.

Brunsdon C, Fotheringham AS, Charlton ME. 1996. Geographicallyweighted regression: a method for exploring spatial nonstationarity.Geographical Analysis, 28(4), 281-298.

Caesar, J., Alexander, L., and Vose, R., 2006. Large-scale changes in observe daily maximum and minimum temperatures: Creation and analysis of a new gridded data set. Journal of Geophysical Research: Atmospheres, 111 D05101. doi: 10.1029/2005jd006280.

Capel Molina, J.J., 1998. Ritmo anual de las temperaturas en España. Nimbus, 1-2, 17-36. 
730 Christy, J.R., Norris, W.B. and McNider, R.T., 2009. Surface temperature 731 variations in east Africa and possible causes. Journal of Climate, 22 (12), 732 3342-3356.

733 Cowtan, K. and Way, R.G., 2014. Coverage bias in the HadCRUT4 temperature 734 series and its impact on recent temperature trends. Quarterly Journal of the 735 Royal Meteorological Society, 140 (683), 1935-1944.

736 Dai, A., Fung, I.Y., and Del Genio, A.D., 1997. Surface observed global land 737 precipitation variations during 1900-88. Journal of Climate, 10 (11), 29432962.

739 Daly, C., Halbleib, M., Smith, J.I., Gibson, W.P., Matthew K. Doggett, a G.H.T., 740 Curtisb, J., and Pasteris, P.P., 2008. Physiographically sensitive mapping 741 of climatological temperature and precipitation across the conterminous $742 \quad$ United States. International Journal of Climatology, 28, 2031-2064.

743 Di Piazza, A., Conti, F. Lo, Noto, L. V., Viola, F. and La Loggia, G., 2011. 744 Comparative analysis of different techniques for spatial interpolation of 745 746 rainfall data to create a serially complete monthly time series of precipitation for Sicily, Italy. International Journal of Applied Earth Observation and Geoinformation, 13 (3), 396-408.

Font Tullot, I., 1983. Climatología de España y Portugal. Ediciones Universidad de Salamanca, Salamanca.

Frei, C., 2013. Interpolation of temperature in a mountainous region using nonlinear profiles and non-Euclidean distances. International Journal of Climatology, 34 (5), 1585-1605. DOI: 10.1002/joc.3786.

Gonzalez-Hidalgo, J.C., Peña-Angulo, D., Brunetti, M. and Cortesi, N., 2015a. MOTEDAS: a new monthly temperature database for mainland Spain and the trend in temperature (1951-2010). International Journal of Climatology, DOI: $10.1002 / j o c .4298$.

Gonzalez-Hidalgo, J.C., Peña-Angulo, D., Brunetti, M. and Cortesi, N., 2015b. 762 the spatial interpolation of rainfall. Journal of Hydrology, 228 (1-2), 113763 129. 
764 Hayakawa, Y.S., Oguchi, T., and Lin, Z., 2008. Comparison of new and existing global digital elevation models: ASTER G-DEM and SRTM-3. Geophysical Research Letters, 35 L17404. Doi: 10.1029/2008gl035036.

Hengl, T., 2007. A Practical Guide to Geostatistical Mapping of Environmental Variables.JCR Scienctific and Technical Reports. European Community, Luxembourg. Available at http://spatial-analyst.net/book/, (ISBN 978-909024981-0).

Hengl, T., Heuvelink, G.B.M. and Rossiter, D.G., 2007. About regressionkriging: From equations to case studies. Computers and Geosciences, 33 (10), 1301-1315.

Hengl, T., Heuvelink, G.B.M. and Stein, A., 2004. A generic framework for spatial prediction of soil variables based on regression-kriging. Geoderma, 120 (1-2), 75-93.

Herrera, S., Gutiérrez, J.M., Ancell, R., Pons, M.R., Frías, M.D. and Fernández, J., 2012. Development and analysis of a 50-year high-resolution daily gridded precipitation dataset over Spain (Spain02). International Journal of Climatology, 32 (1), 74-85.

Hofstra, N., Haylock, M., New, M., Jones, P., and Frei, C., 2008. Comparison of six methods for the interpolation of daily, European climate data. Journal of Geophysical Research: Atmospheres, 113 (21), D21110. Doi: 10.1029/2008jd010100.

Hosseini, E., Gallichand, J. and Caron, J., 1993. Comparison of several interpolators for smoothing hydraulic conductivity data in South West Iran. American Society of Agricultural Engineers, 36 (6), 1687-1693.

Jones, P.D. and Hulme, M., 1996. Calculating regional climatic time series for temperature and precipitation: Methods and illustrations. International Journal of Climatology, 16, 361-377.

Jones, P.D., New, M., Parker, D.E., Martin, S. and Rigor, I.G., 1999. Surface air temperature and its changes over the past 150 years. Reviews of Geophysics, 37 (2), 173-199.

Klotzbach, P.J., Pielke, R. a., Pielke, R.A., Christy, J.R. and McNider, R.T., 2009. An alternative explanation for differential temperature trends at the surface and in the lower troposphere. Journal of Geophysical Research, 114, D21102, doi:10.1029/2009JD011841. 
798 Kurtzman, D. and Kadmon, R., 1999. Mapping of temperature variables in 799 Israel: A comparison of different interpolation methods. Climate Research,

800

801

802

803

804

805

806

807

808

809

810

811

812

813

814

815

816

817

818

819

820

821

822

823

824

825

826

827

828

829

830

831 13 (1), 33-43.

Legates, D.R. and McCabe Jr., G.J., 1999. Evaluating the use of 'goodness-offit' measures in hydrologic and hydroclimatic model validation. Water resources research, 35 (1), 233-241.

Li, J. and Heap, A.D., 2011. A review of comparative studies of spatial interpolation methods in environmental sciences: Performance and impact factors. Ecological Informatics, 6 (3-4), 228-241.

Madden, R.A., Shea, D.J., Branstator, G.W., Tribbia, J.J., and Weber, R.O., 1993. The Effects of Imperfect Spatial and Temporal Sampling on Estimates of the Global Mean Temperature: Experiments with Model Data. Jurnal of Climate, 6, 1057-1066.

McNider, R.T., Christy, J.R., and Biazar, A, 2010. A stable boundary layer perspective on global temperature trends. InIOP Conference Series: Earth and Environmental Science, 13, 012003. Doi: 10.1008/17551315/13/1/012003.

Mitchell, T.D. and Jones, P.D., 2005. An improved method of constructing a database of monthly climate observations and associated high-resolution grids. International Journal of Climatology, 25 (6), 693-712.

Nalder, I.A. and Wein, R.W., 1998. Spatial interpolation of climatic Normals: test of a new method in the Canadian boreal forest. Agricultural and Forest Meteorology, 92, 211-225.

New, M., Hulme, M. and Jones, P., 2000. Representing twentieth-century space-time climate variability. Part II: Development of 1901-96 monthly grids of terrestrial surface climate. Journal of Climate, 13 (13), 2217-2238.

Ninyerola, M., Pons, X. and Roure, J.M., 2000. A Methodological Approach of Climatological Modelling of Air Temperature and Precipitation. International Journal of Climatology, 1841 (20), 1823-1841.

Ninyerola, M., Pons, X, and Roure, J.M., 2005. Atlas climático digital de la Península Ibérica Metodología y aplicaciones en bioclimatología y geobotánica Información. Universitat Autònoma de Barcelona Departament de Biologia Animal, Biologia Vegetal i Ecologia (Unitat de Botànica) Departament de Geografia. Barcelona, España. 
832 Ninyerola, M., Pons, X. and Roure, J.M., 2007. Objective air temperature

833

834

835

836

837

838

839

840

841

842

843

844

845

846

847

848

849

850

851

852

853

854

855

856

857

858

859

860

861

862

863

864 mapping for the Iberian Peninsula using spatial interpolation and GIS. International Journal of Climatology, 27, 1231-1242.

Peña-Angulo, D., Cortesi, N., Brunetti, M.and González-Hidalgo, J.C., 2015. Spatial variability of maximum and minimum monthly temperature in Spain during 1981-2010 evaluated by correlation decay distance (CDD). Theorical and Applied Climatology, 122, 35-45.

Pielke, R.A., 1984. Mesoscale Meteorological Modeling. Quaterly Journal of the Royal Meteorological Society, 111, 671-672.

Pons, X., 1996. Estimación de la Radiación Solar a partir de modelos digitales de elevaciones. Propuesta metodológica. InJ. Juaristiand I Moro, eds. VII Coloquio de Geografía Cuantitativa, Sistemas de Información Geográfica y Teledetección. Vitoria-Gasteiz, Asociación de Geógrafis Españoles, 87-94.

Sánchez O. and Sánchez F, 1999. Modelos y cartografía de estimaciones climáticas termopluviométricas para la España peninsular. Ministerio de Agricultura, Pesca y Alimentación. Instituto Nacional de Investigación y Tecnología Agraria y Alimentaria. ISBN: 84-749847-0-X. 192 p.

Taylor, J.R., 1997. An Introduction to Error Analysis: The Study of Uncertainties in Physical Measurements. University Science Books, Sausalito, CA. 345 p.

Tveito, O.E., Wegehenkel, M. and Wel, F., 2008. The use of geographic information systems in Climatology and Meteorology. COST Action 719ESSEM.

USGS, 1996. Global 30 Arc-Second Elevation (GTOPO30). United States Geological Survery.

Vicente-Serrano, S.M., Saz-Sánchez, M.A., and Cuadrat, J.M., 2003. Comparative analysis of interpolation methods in the middle Ebro Valley (Spain): Application to annual precipitation and temperature. Climate Research, 24 (2), 161-180.

Willmott, C.J., 1982. Some comments on the evaluation of model performance. Bulletin of the American Meteorological Society, 63 (11), 1309-1313. 
1

2

3

4

5

6

7

8

9

10

11

12

13

14

15

16

17

18

19

20

21

22

23

24

25

26

27

28

29

30

31

32

33

34

35

36

37

38

39

40

41

42

43

44

45

46

47

48

49

50

51

52

53

54

55

56

57

58

59

60

\section{FIGURE CAPTIONS}

866

867 Figure 1. Study area. The map shows the topography of Iberian Peninsula, and

868 the names of the most important spatial units quoted in the text

869 Figure 2. Spatial distribution of the meteorological stations by altitudinal

870 intervals

871 Figure 3. Tmax and Tmin Mean Bias Error (MBE) for different elevation bands

872 annual values are shown together January and July

873 Figure 4. Monthly mean climatology for Tmax

874 Figure 5. Monthly mean climatology for Tmin

875 Figure 6. Monthly mean climatology for DTR

876 Figure 7. Confidence interval (68\%) estimated for the LWLR Tmax and Tmin

877 reconstructions for January and July 


\begin{tabular}{|c|c|c|c|c|c|c|c|c|c|c|c|c|c|c|c|}
\hline \multirow{2}{*}{ Tmax } & \multicolumn{5}{|c|}{ LWLR } & \multicolumn{5}{|c|}{ RK } & \multicolumn{5}{|c|}{ RKS } \\
\hline & MBE & MSE & MAE & $\mathrm{R}^{2}$ & D & $\mathrm{BBE}$ & MSE & MAE & $\mathrm{R}$ & D & MBE & MSE & MAE & $\mathrm{R}^{2}$ & $\mathrm{D}$ \\
\hline $\mathrm{Ja}$ & 006 & 23 & 08 & 27 & 1 & 1 & 323 & 605 & 0.927 & 1 & 02 & 832 & 0,612 & .925 & .98 \\
\hline & & & & & & & & & 2 & & & & & & 97 \\
\hline N & 020 & 60 & 44 & 7 & & 0,00 & 90 & 667 & 0.901 & c & & 890 & 0,668 & .901 & .97 \\
\hline & 024 & 913 & 580 & 0.907 & 0 & 0 & 947 & 706 & 0.901 & c & 0,001 & ,937 & 0,698 & .903 & .97 \\
\hline May & 031 & 978 & 736 & 8 & ( & 0,002 & 36 & 775 & 0.887 & c & 0 & 02 & 52 & 94 & .97 \\
\hline June & $-0,038$ & 0 & & & & & & & & & & & 9 & & .97 \\
\hline J & 037 & 53 & 0 & 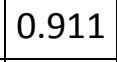 & 0.97 & 0,002 & 2 & 16 & c & c & $-0,002$ & 38 & 95 & 7 & 07 \\
\hline$A$ & 040 & 133 & 856 & 0.906 & 0 & 0 & 223 & 912 & 0.891 & 0 & 1 & ,157 & 0,869 & 0.903 & a- \\
\hline ep & $-0,033$ & 993 & 0,747 & 0.899 & 0.972 &, 000 & 047 & 0,782 & 0.888 & 0.968 & $-0,001$ & 1,014 & 0,763 & 0.895 & .97 \\
\hline Oct & $-0,020$ & 863 & 0,642 & 0.910 & 0.976 & 0,001 & 884 & 0,657 & 0.906 & 0.974 &, 003 & ,888 & 0,659 & 0.905 & .97 \\
\hline NC & 009 & 823 & 08 & 25 & 0 & 0,001 & 320 & 0,604 & 926 & c & $v$ & 832 & 0,615 & .924 & .5 \\
\hline December &, 006 & 839 & 520 & 0.924 & 0 & 0,001 & 344 & 0,620 & 924 & c & 0,002 & 845 & 0,621 & 0.924 & .50 \\
\hline foma & $-0,023$ & 0,813 & 0,612 & 0.919 & 0.510 & ( & 0,848 & 0,633 & 0.904 & 0.976 & I & 0,844 & 0,633 & 0.908 & 0.51 \\
\hline
\end{tabular}

Table 1. Monthly and anual error model measurements for Tmax. 


\begin{tabular}{|c|c|c|c|c|c|c|c|c|c|c|c|c|c|c|c|}
\hline \multirow{2}{*}{ Tmin } & \multicolumn{3}{|c|}{ LWLR } & \multicolumn{1}{|c|}{ RK } & \multicolumn{5}{c|}{ RKS } \\
\cline { 2 - 5 } & MBE & RMSE & MAE & $R^{2}$ & D & MBE & RMSE & MAE & $R^{2}$ & D & MBE & RMSE & MAE & $R^{2}$ & D \\
\hline January & $-0,007$ & 1,020 & 0,796 & 0.882 & 0.968 & 0,000 & 1,193 & 0,936 & 0.841 & 0.957 & $-0,001$ & 1,089 & 0,864 & 0.865 & 0.963 \\
\hline Febrary & $-0,009$ & 1,020 & 0,801 & 0.883 & 0.969 & $-0,001$ & 1,172 & 0,928 & 0.848 & 0.959 & $-0,001$ & 1,085 & 0,864 & 0.868 & 0.964 \\
\hline March & $-0,005$ & 1,024 & 0,808 & 0.873 & 0.965 & $-0,001$ & 1,148 & 0,915 & 0.842 & 0.957 & $-0,001$ & 1,085 & 0,867 & 0.857 & 0.961 \\
\hline April & 0,003 & 0,968 & 0,765 & 0.880 & 0.968 & $-0,002$ & 1,048 & 0,831 & 0.861 & 0.963 & $-0,004$ & 1,013 & 0,802 & 0.869 & 0.964 \\
\hline May & 0,004 & 1,000 & 0,785 & 0.865 & 0.963 & 0,001 & 1,054 & 0,831 & 0.850 & 0.959 & $-0,002$ & 1,040 & 0,819 & 0.854 & 0.960 \\
\hline June & 0,005 & 1,104 & 0,856 & 0.852 & 0.959 & 0,003 & 1,137 & 0,887 & 0.844 & 0.957 & 0,000 & 1,141 & 0,892 & 0.843 & 0.957 \\
\hline July & 0,005 & 1,248 & 0,959 & 0.844 & 0.956 & 0,003 & 1,291 & 0,998 & 0.833 & 0.954 & 0,001 & 1,296 & 1,004 & 0.832 & 0.953 \\
\hline August & 0,001 & 1,256 & 0,966 & 0.854 & 0.960 & 0,001 & 1,320 & 1,025 & 0.839 & 0.956 & 0,000 & 1,311 & 1,018 & 0.841 & 0.956 \\
\hline September & $-0,002$ & 1,178 & 0,917 & 0.864 & 0.963 & 0,000 & 1,285 & 1,011 & 0.840 & 0.956 & $-0,001$ & 1,249 & 0,984 & 0.847 & 0.958 \\
\hline October & $-0,004$ & 1,064 & 0,838 & 0.879 & 0.967 & $-0,001$ & 1,216 & 0,966 & 0.845 & 0.958 & $-0,001$ & 1,143 & 0,911 & 0.861 & 0.962 \\
\hline November & $-0,009$ & 1,031 & 0,808 & 0.887 & 0.970 & 0,000 & 1,215 & 0,956 & 0.846 & 0.958 & 0,001 & 1,109 & 0,881 & 0.869 & 0.964 \\
\hline December & $-0,005$ & 1,018 & 0,791 & 0.885 & 0.969 & $-0,001$ & 1,199 & 0,937 & 0.844 & 0.958 & 0,000 & 1,089 & 0,859 & 0.869 & 0.964 \\
\hline Annual & $-0,002$ & 1,011 & 0,797 & 0.877 & 0.967 & $-0,001$ & 1,130 & 0,899 & 0.844 & 0.960 & $-0,002$ & 1,078 & 0,860 & 0.856 & 0.962 \\
\hline
\end{tabular}

Table 2. Monthly and anual error model measurements for Tmin. 


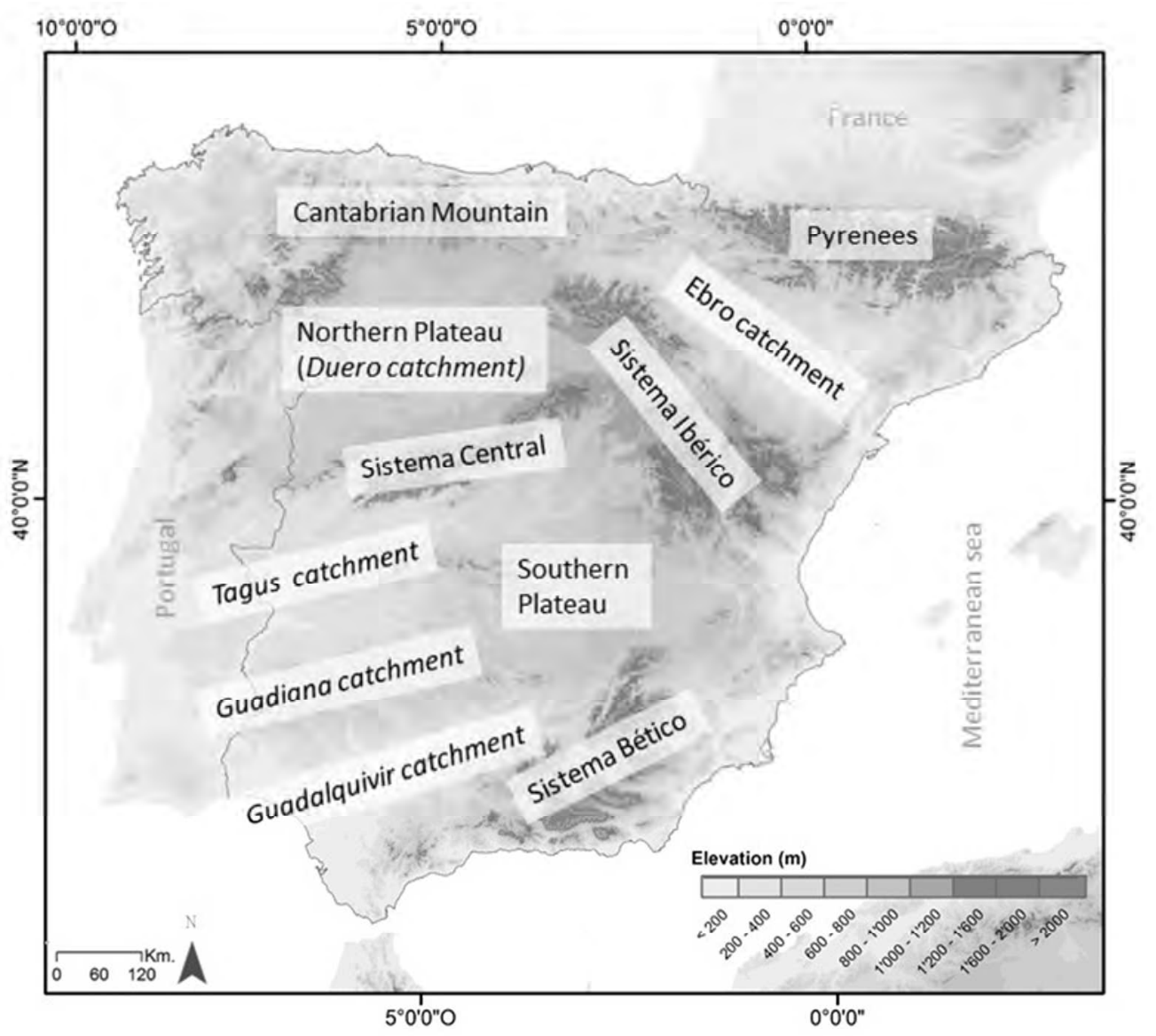

Study area. The map shows the topography of Iberian Peninsula, and the names of the most important spatial units quoted in the text 


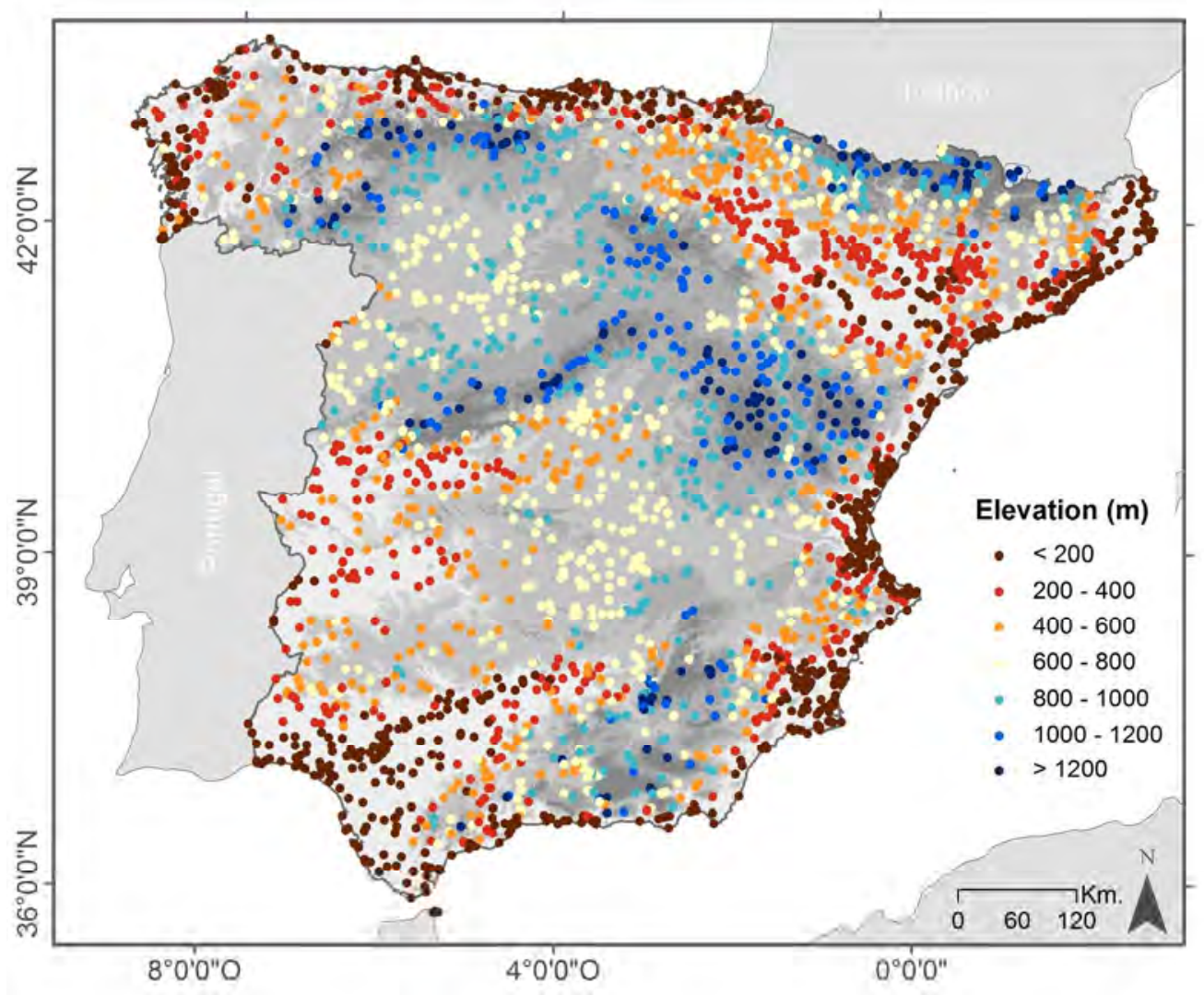

Spatial distribution of the meteorological stations by altitudinal intervals 
LWLR
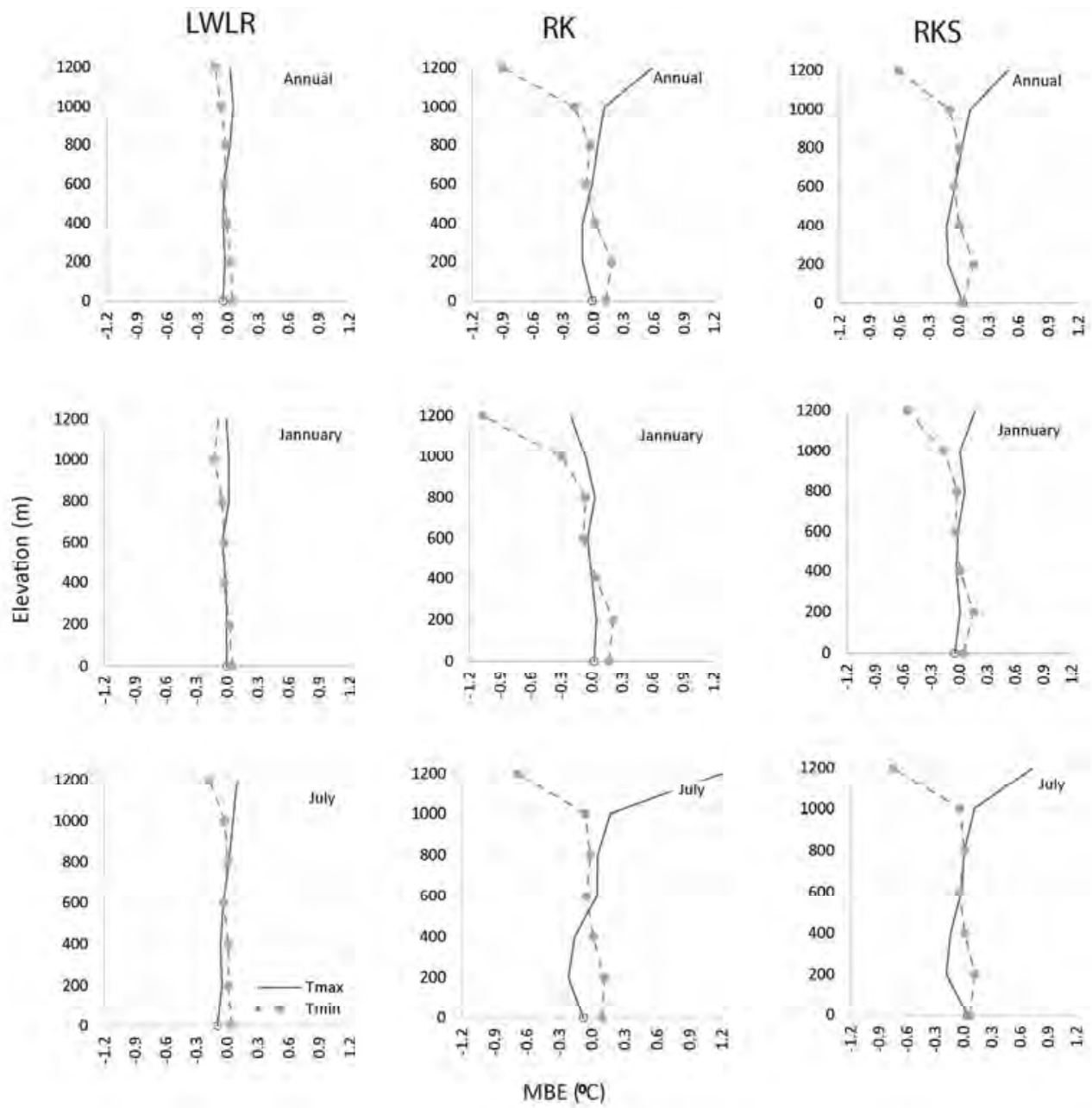

Tmax and Tmin Mean Biass Error (MBE) for different elevation bands annual values are shown together January and July $965 \times 951 \mathrm{~mm}(72 \times 72$ DPI $)$ 

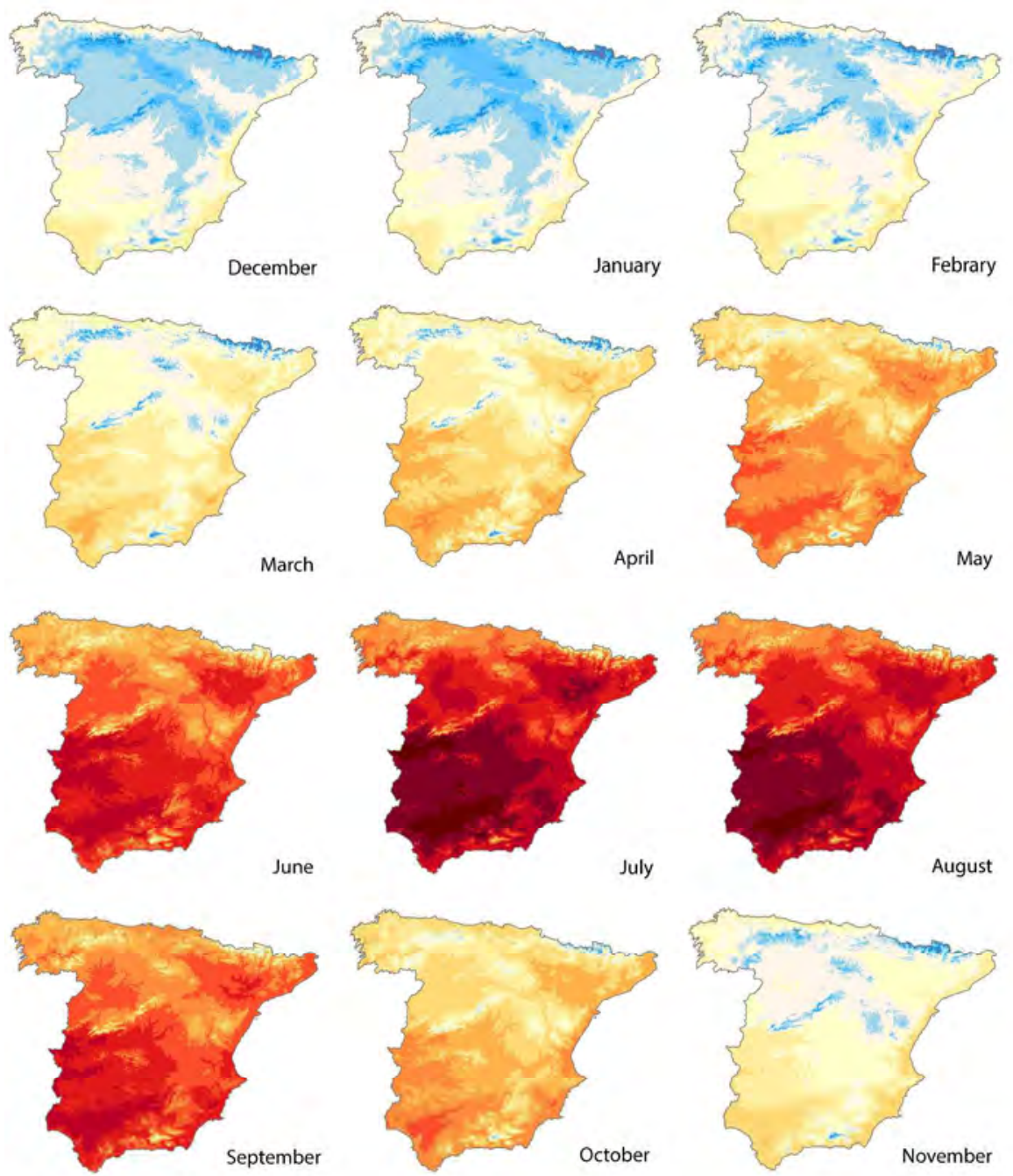

${ }^{\circ C}$

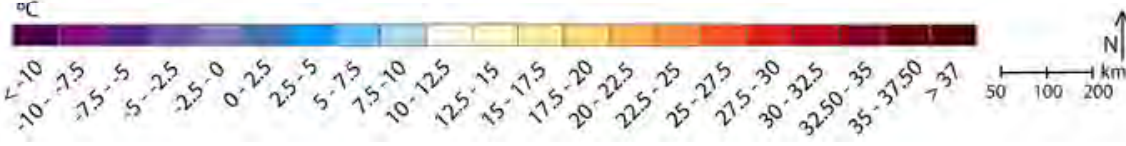

Monthly mean climatology for Tmax

$282 \times 375 \mathrm{~mm}(300 \times 300 \mathrm{DPI})$ 

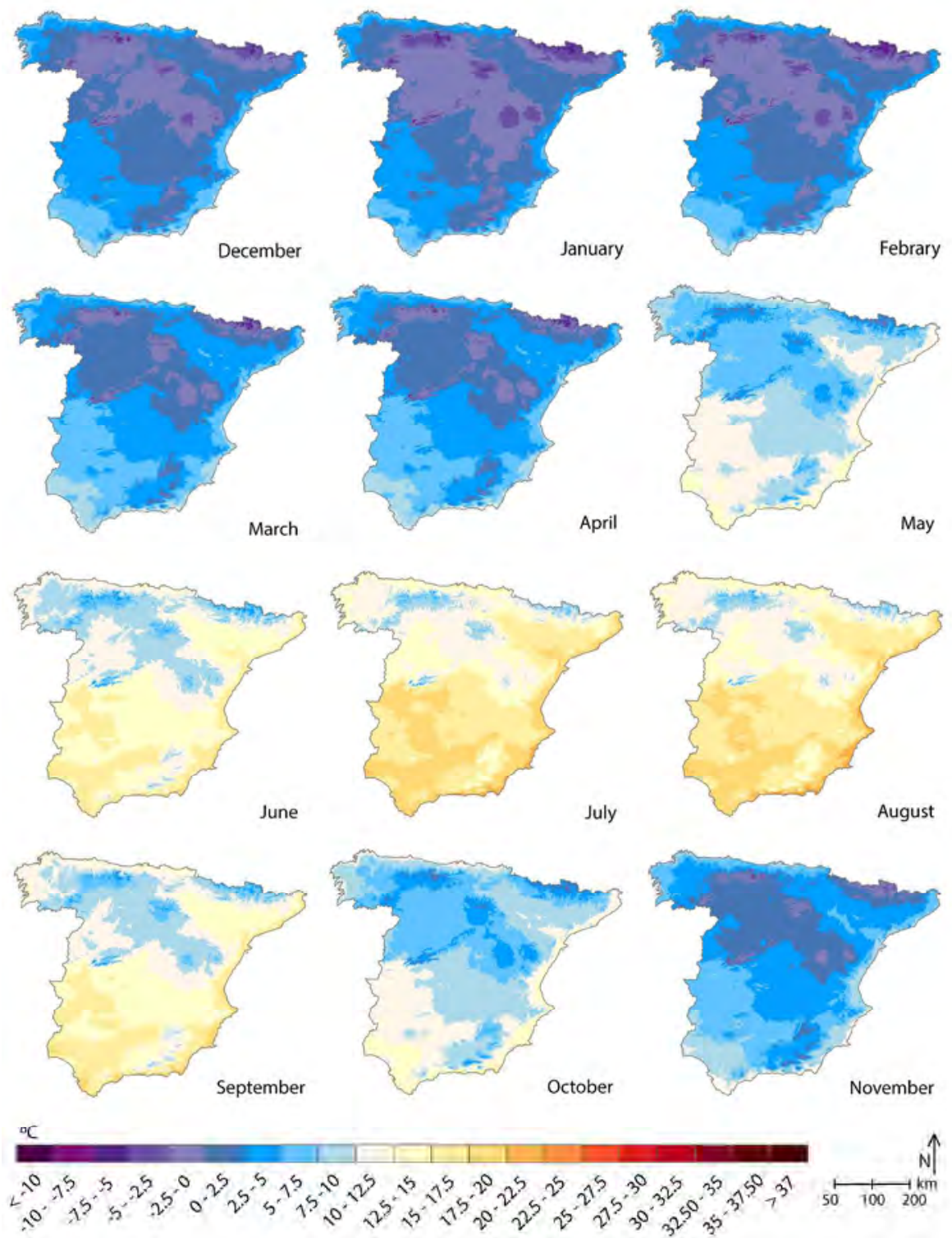

Monthly mean climatology for Tmin $282 \times 373 \mathrm{~mm}(300 \times 300$ DPI $)$ 

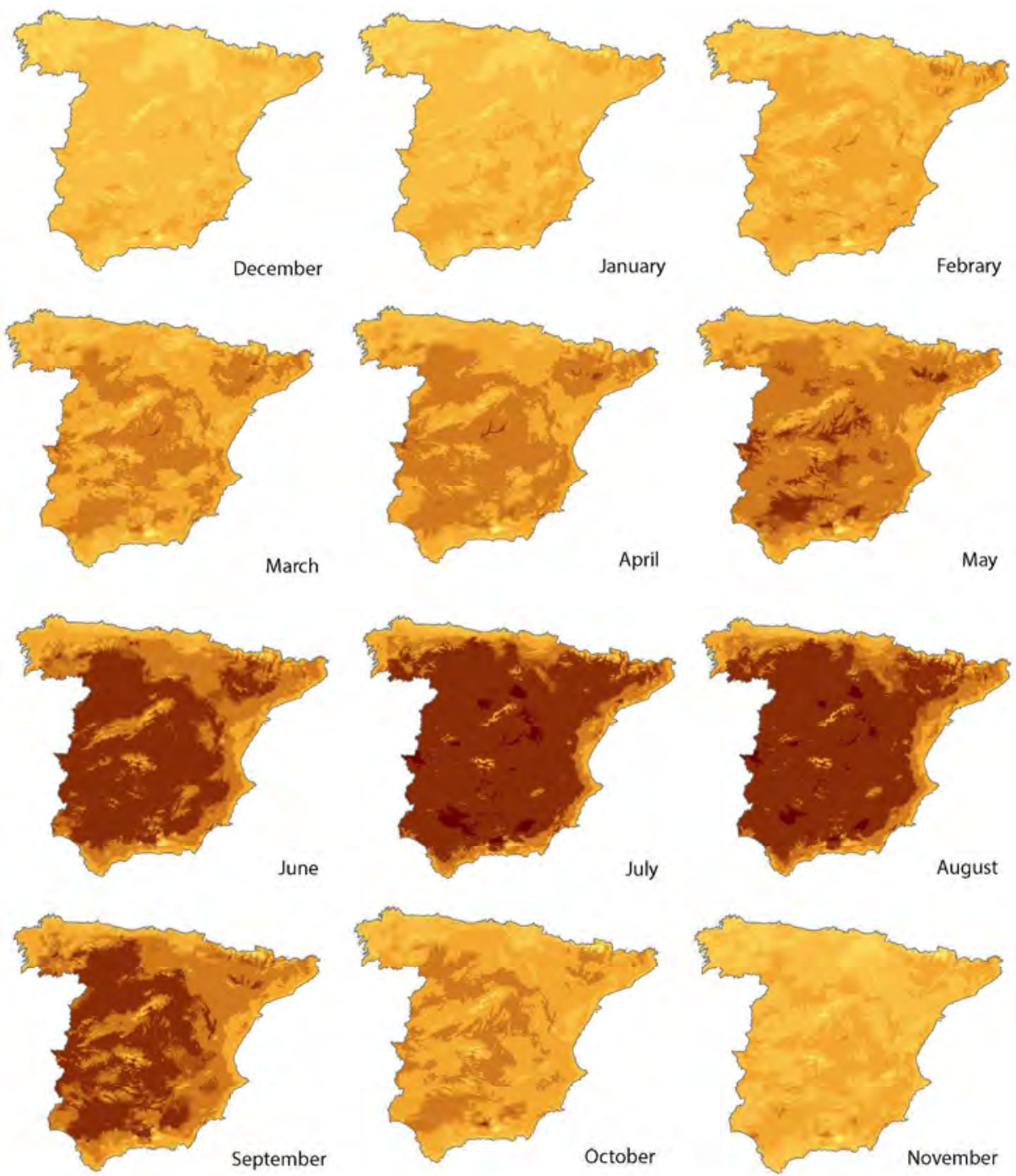

${ }^{\circ C}$
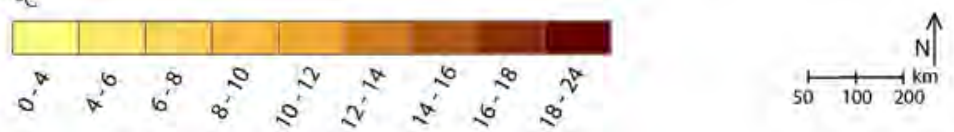

Monthly mean climatology for DTR $214 \times 271 \mathrm{~mm}(300 \times 300 \mathrm{DPI})$ 

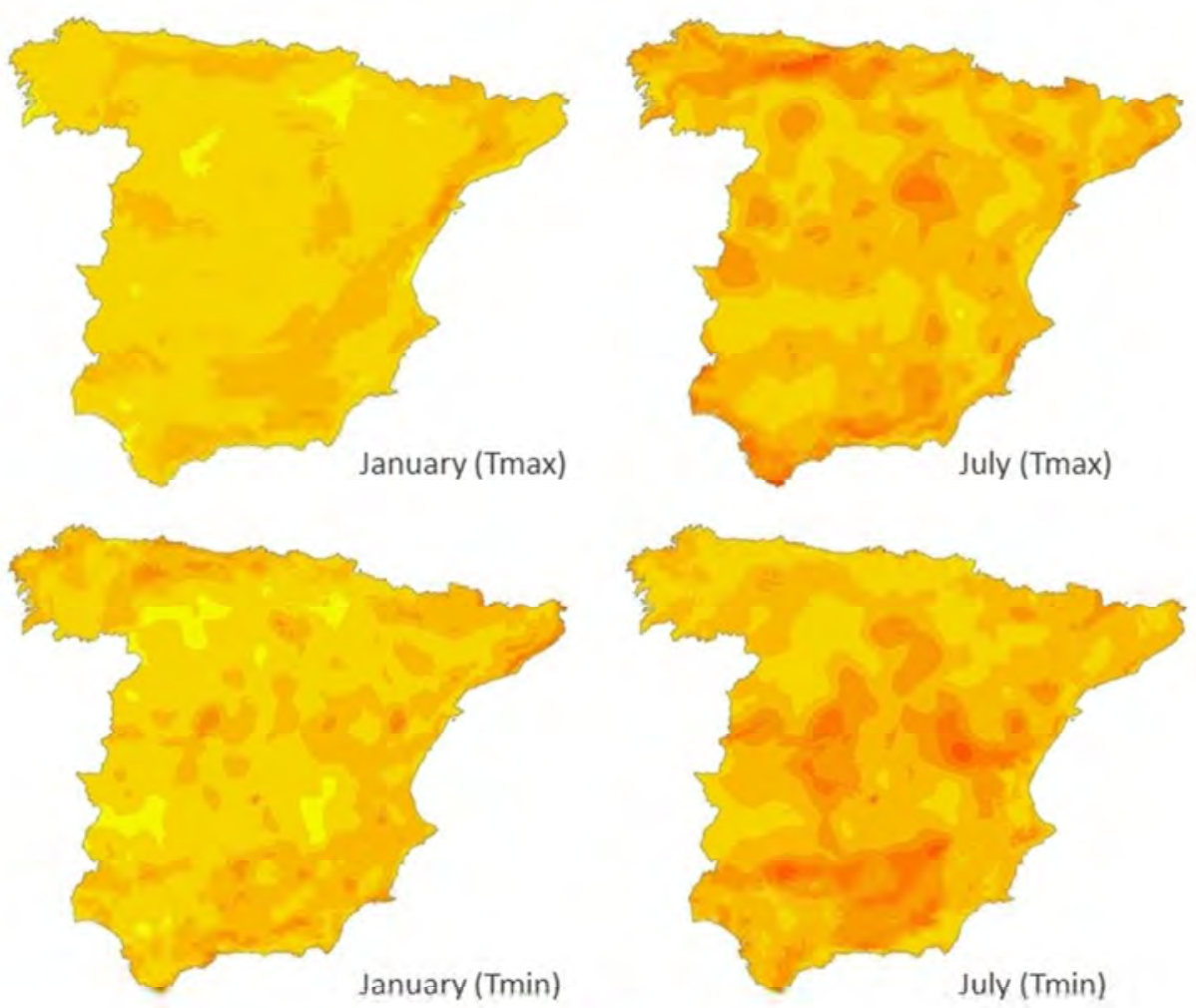

${ }^{\circ} \mathrm{C}$
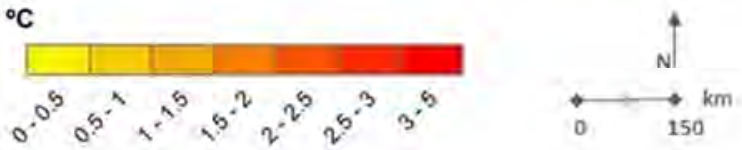

Confidence interval (68\%) estimated for the LWLR Tmax and Tmin reconstructions for January and July 